\title{
Persepsi Karyawan Terhadap Senam Peregangan di Puskesmas Kebon Jeruk
}

\section{Employee Perception of Stretching Gymnastics at Kebon Jeruk Health Center}

\author{
Tommy G ${ }^{1}$, Rahmi Kartini Pertiwi2 ${ }^{2}$ Pelita Juliana Gultom ${ }^{3}$, Laras Sitoayu ${ }^{4}$, Nazhif Gifari45, \\ Vira Herliana Putri ${ }^{6}$ \\ 1-5 Program Studi Profesi Pendidikan Dietisien Fakultas IImu-ilmu Kesehatan, Universitas Esa \\ Unggul, Indonesia \\ ${ }^{6}$ Program Studi IImu Gizi Fakultas IImu-ilmu Kesehatan, Universitas Esa Unggul, Indonesia \\ email: tmmygth@gmail.com¹, rahmikarini.rd@gmail.com², pjulianagultom@gmail.com³ , \\ laras@esaunggul.ac.id ${ }^{4}$, nazhif.gifari@esaunggul.ac.id ${ }^{5}$, viraherlianaputri@gmail.com6
}

\section{: https://doi.org/10.20884/1.paju.2021.3.1.4708}

\begin{abstract}
Abstrak
Aktivitas fisik bermanfaat untuk promosi kesehatan dan pencegahan penyaki, serta mengontrol berat badan, karena aktivitas fisik meningkatkan kapasitas fungsional tubuh melalui peningkatan konsumsi oksigen maksimal (VO2 max), komposisi tubuh, kekuatan otot, daya tahan, dan fleksibilitas. Saat ini, Puskesmas Kecamatan Kebon Jeruk mempunyai program kegiatan gizi olahraga yaitu senam peregangan, berupa pemutaran audio di area puskesmas dengan melakukan peregangan untuk seluruh karyawan. Penelitian ini dilakukan untuk mengukur persepsi tenaga kesehatan di lingkungan kerja Puskesmas Kebon Jeruk terkait program peregangan yang telah berjalan, sehingga dapat dijadikan sebagai bahan kajian dalam pengembangan program gizi olahraga. Pengumpulan data dilakukan menggunakan kuesioner online yang diadopsi dari Instrument to Measure Health Promotion Model (HPM) Behavioral Determinants: Exercise Benefits/Barriers Scale (EBBS) Karakter responden yang berpartisipasi pengisian kuesioner sebanyak 23 orang wanita dan 11 orang pria. Hasil penelitian menyatakan terdapat hubungan antara pemahaman terkait manfaat aktivitas fisik dengan persepsi terhadap senam peregangan dengan arah hubungan positif. Kesimpulan dari penelitian ini yaitu semakin baik persepsi seseoang mengenai manfaat aktivitas fisik dan olahraga maka semakin baik pula jenis aktivitas fisik dan olahraga yang dilakukan secara terprogram.
\end{abstract}

Kata Kunci : Aktivitas Fisik, Persepsi, Senam Peregangan

\section{Abstract}

Physical activity is beneficial for health promotion and disease prevention, as well as weight control, because physical activity increases the body's functional capacity by increasing maximal oxygen consumption (VO2 max), body composition, muscle strength, endurance, and flexibility. Currently, the Kebon 
Jeruk District Health Center has a sports nutrition activity program, namely stretching exercises, in the form of audio playback in the puskesmas area by stretching for all employees. This study was conducted to measure the perception of health workers in the work environment of the Kebon Jeruk Public Health Center related to the stretching program that has been running, so that it can be used as study material in the development of sports nutrition programs. Data was collected using an online questionnaire adopted from the Instrument to Measure Health Promotion Model (HPM) Behavioral Determinants: Exercise Benefits/Barriers Scale (EBBS). The character of respondents who participated in filling out the questionnaire were 23 women and 11 men. The results of the study stated that there was a relationship between the understanding of the benefits of physical activity and the perception of stretching exercises in a positive direction. The conclusion of this study is that the better one's perception of the benefits of physical activity and exercise, the better the type of physical activity and exercise that is programmed.

Keywords : Perception, Physical activity, Stretching

\section{PENDAHULUAN}

Berdasarkan data Riskesdas tahun 2018 diketahui bahwa proporsi rendahnya aktivitas fisik di Indonesia mengalami peningkatan sebesar 7,4 dibandingkan tahun 2013. Resiko dari menurunnya aktivitas fisik apat meningkatkan 6-10\% kejadian penyakit tidak menular (Abadini \& Wuryaningsih, 2019). Untuk menurunkan resiko terjadinya penyakit tidak menular dibutuhkan upaya untuk meningkatkan kesehatan dan kebugaran jasmani termasuk pada tenaga Kesehatan, dapat dilakukan dengan meningkatkan aktivitas fisik, latihan fisik, dan olahraga (Direktorat Kesehatan Tenaga Kerja dan Olahraga, 2019). Di Puskesmas Kecamatan Kebon Jeruk, karyawan melakukan aktivitas fisik secara rutin berupa senam peregangan, yang dilakukan sebanyak dua kali dalam sehari selama bekerja sebagai upaya untuk meningkatkan aktivitas fisik pada tenagan kesehatan.

Pada Maret 2020, Indonesia dihadapkan pada situasi pandemi Coronavirus Disease 2019 (COVID-19). Tenaga kesehatan adalah orang yang memiliki risiko lebih tinggi untuk penularan penyakit dan rentan tertular virus tersebut. Karyawan Puskesmas adalah salah satu kelompok tanggap COVID-19 yang bertanggung jawab terhadap penanganan awal COVID-19 lingkup ada lingkup kecamatan. Gejala awal COVID-19 menyerang sindrom pernafasan berat, penyakit ini dikategorikan sebagai infeksi menular dengan cara perpindahan droplet saluran pernafasan dan kontak langsung dengan pasien positif COVID-19 (Wicaksono \& Ariif, 2020). Pandemi COVID-19 telah mengorbankan 22.138 penduduk Indonesia meninggal, dan sebanyak 342 tenaga kesehatan gugur 
Tommy G, Rahmi Kartini Pertiwi, Pelita Juliana Gultom, Laras Sitoayu, Nazhif Gifari \& Vira Herliana Putri I Persepsi Karyawan Terhadap Senam Peregangan di Puskesmas Kebon Jeruk

selama pandemi per 5 September 2020 (Sugiono \& Arif, 2020).

Berdasarkan Pedoman Penanganan Cepat Medis dan Kesehatan Masyarakat COVID-19 di Indonesia tahun 2020, menjaga imunitas merupakan hal yang penting untuk mencegah COVID-19, dan rekomendasi untuk meningkatkan imun, meliputi konsumsi gizi seimbang, istirahat cukup, suplemen vitamin, tidak merokok, mengendalikan komorbid, dan melakukan aktivitas fisik bisa dilakukan dengan senam ringan

Aktivitas fisik dapat diartikan dengan melakukan gerakan tubuh yang melibatkan kerja otot rangka dan meningkatkan pengeluaran energi (Budi et al., 2021; Widanita et al., 2019). Aktivitas fisik dibagi menjadi 3 kategori berdasarkan intensitas dan besaran kalori yang dikeluarkan yaitu aktivitas fisik ringan, aktivitas fisik sedang, dan aktivitas fisik berat (P2PTM, 2018). Aktivitas fisik memiliki manfaat untuk promosi kesehatan dan pencegahan penyakit. Hal ini berkaitan dengan peningkatan konsumsi oksigen maksimal (VO2 max), komposisi tubuh, kekuatan otot, daya tahan, dan fleksibilitas

Individu memiliki persepsi yang berbeda-beda dalam memahami dan menilai suatu obyek yang dipengaruhi oleh beberapa faktor, seperti: sumber informasi, pengetahuan dan pengalaman (Sumarni, 2015). Persepsi terhadap aktivitas fisik mempengaruhi aktivitas fisik yang dilakukan oleh masyarakat, termasuk tenaga kesehatan. Persepsi yang baik perlu didukung dengan pemahaman atau pengetahuan yang baik. Pengetahuan yang baik akan meningkakan ketertarikan masyarakat terhadap aktivitas fisik sebagai upaya menjaga kebugaran (Yudho et al., 2020).

Saat ini, Puskesmas Kecamatan Kebon Jeruk melaksanakan program kegiatan gizi olahraga berupa senam peregangan. Senam peregangan berbentukk pemutaran audio di area Puskesmas, dan menghimbau seluruh karyawan ikut senam eregangan. Penelitian ini dilakukan untuk menganalisis hubungan antara profil tenaga Kesehatan dan pengetahuan dengan persepsi mengenai senam peregangan di lingkungan kerja Puskesmas Kebon Jeruk yang telah berjalan, sehingga dapat digunakan sebagai bahan kajian untuk pengembangan program gizi olahraga pada institusi.

\section{METODE}

Penelitian dilakukan di Puskesmas Kecamatan Kebon Jeruk, Jakarta Barat pada bulan Februari 2021. Jenis dan desain penelitian yang digunakan ialah cross-sectional. Penelitian ini bertujuan untuk menganalisis persepsi terhadap kegiatan senam 
peregangan di Puskesmas Kebon Jeruk. Populasi pada penelitian ini seluruh karyawan Puskesmas Kecamatan Kebon Jeruk sebanyak 234 karyawan. Sampel yang digunakan pada penelitian ini berjumlah 34 orang, yang diambil menggunakan purposive sampling dengan kriteria bersedia berpartisipasi dalam penelitian, dalam keadaan sehat dan merupakan tenaga kesehatan di wilayah Puskesmas Kecamatan Kebon Jeruk.

Pengumpulan data pada penelitian ini dilakukan oleh 3 orang mahasiswa program profesi dietisien Universitas Esa Unggul dengan menggunakan kuesioner online, yang disebarkan melalui aplikasi Whatsapp. Kuesioner terdiri dari 3 (tiga) bagian yaitu, identifikasi karakteristik responden, pengetahuan terkait manfaat aktivitas fisik dan persepsi terhadap senam peregangan, dengan menggunakan beberapa pertanyaan singkat tertutup. Kuesioner diadopsi dari Instrument to Measure Health Promotion Model (HPM) Behavioral Determinants: Exercise Benefits/Barriers Scale (EBBS) (Sechrist \& R, 1987).

\section{HASIL}

\section{Karakteristik Responden}

Tabel 1 menunjukkan karakteristik responden, jumlah dan jenis kelamin responden pada penelitian ini. Berdasarkan hasil pengolahan data diketahui bahwa jumlah responden yang berpartisipasi mengisi kuesioner sebanyak $67,6 \%$ berjenis kelamin wanita. Berdasarkan tingkat pendidikannnya, sebagian besar responden berpendidikan $\mathrm{SI}$, yaitu sebanyak $70,6 \%$ dan sisanya berpendidikan D3

Tabel 1. Karakteristik Responden

\begin{tabular}{lcc}
\hline & Frekuensi & Persentase \\
\hline Jenis Kelamin & 11 & \\
Pria & 23 & 32,4 \\
Wanita & 34 & 67,6 \\
Total & & 100 \\
Tingkah Pendidikan & 10 & \\
D3 & 24 & 29.4 \\
S1 & 34 & 70.6 \\
Total & & 100 \\
\hline
\end{tabular}


Tommy G, Rahmi Kartini Pertiwi, Pelita Juliana Gultom, Laras Sitoayu, Nazhif Gifari \& Vira Herliana Putri | Persepsi Karyawan Terhadap Senam Peregangan di Puskesmas Kebon Jeruk

Berdasarkan hasil analisis identifikasi pengetahuan karyawan pada tabel 2 tentang manfaat aktivitas fisik sebanyak $71 \%$ menjawab senam peregangan menurunkan rasa tegang saat kerja, $74 \%$ menjawab senam peregangan membantu menghilangkan rasa pegal, dan senam peregangan membuat responden merasa terhibur. Meskipun demikian, masih ada karyawan yang memiliki pengetahuan kurang terkait manfaat aktivitas fisik/senam peregangan. Berikut hasil analisis mengenai pengetahuan karyawan mengenai manfaat aktivitas fisik.

Tabel 2. Pengetahuan Karyawan Mengenai Manfaat Aktivitas Fisik

\begin{tabular}{lcc}
\hline \multicolumn{1}{c}{ Persepsi } & Frekuensi & Persentase (\%) \\
\hline Senam peregangan menurunkan rasa tegang saat kerja & 24 & 71 \\
Senam peregangan membuat saya merasa rileks & 23 & 68 \\
$\begin{array}{l}\text { Senam peregangan meningkatkan stamina saya dan } \\
\text { kelenturan tubuh saya }\end{array}$ & 23 & 68 \\
$\begin{array}{l}\text { Senam peregangan membantu saya menghilangkan rasa } \\
\text { pegal }\end{array}$ & 25 & 74 \\
Senam peregangan meningkatkan kualitas kerja saya & 23 & 68 \\
Senam peregangan membuat saya merasa terhibur & 25 & 74 \\
\hline
\end{tabular}

Persepsi karyawan terhadap senam peregangan dapat dilihat pada tabel menunjukan bahwa sebanyak $71 \%$ menjawab setuju jika kegiatan senam peregangan terus dilakukan jika kondisi memungkinkan, $74 \%$ menjawab menikmati kegiatan senam peregangan, dan $85 \%$ menjawab senam peregangan memberikan manfaat. Tenaga Kesehatan sebagai garda terdepan saat pandemi, harus selalu memperhatikan aktivitas fisiknya. Dengan persepsi yang baik, diharapkan akan memiliki aktivitas fisik yang baik.

Tabel 3. Persepsi Karyawan Terhadap Senam Peregangan

\begin{tabular}{lcc}
\hline \multicolumn{1}{c}{ Persepsi } & Frekuensi & Persentase (\%) \\
\hline Saya menikmati senam peregangan & 25 & 74 \\
Senam peregangan menyita waktu kerja & 9 & 26
\end{tabular}


Senam peregangan membuat saya lelah

Saya merasa malu melakukan senam peregangan

Jadwal pelaksanaan senam peregangan tidak sesuai dengan waktu kerja

Senam peregangan memberikan manfaat bagi saya

Jika kegiatan senam peregangan terus dilakukan jika kondisi memungkinkan

\section{Analisis Bivariat}

Analisis yang digunakan dalam penelitian ini adalah uji korelasi sperman. Hasil analisis dapat dilihat pada tabel 4 . Berdasarkan hasil pada tabel 4 dapat diketahui bahwa tidak ada hubungan antara persepsi karyawan dengan jenis kelamin $(p=0,109 r=-0,280)$. Hal ini sejalan dengan penelitian yang dilakukan oleh Akhmad et al., 2015 yang menyatakan bahwa tidak ada perbedaan persepsi baik pada laki-laki dan perempuan.

Tabel 4. Analisis Bivariat Dengan Korelasi

\begin{tabular}{lcc}
\hline Variabel & \multicolumn{2}{c}{ Persepsi Karyawan } \\
& Korelasi $(r)$ & $p$-Value \\
\hline Jenis Kelamin & $-0,280$ & 0,109 \\
Tingkat Pendidikan & $-0,150$ & 0,396 \\
Pengetahuan Karyawan Mengenai & 0,369 & 0,032 \\
Aktivitas Fisik & & \\
\hline
\end{tabular}

\section{PEMBAHASAN}

Responden pada penelitian ini didominasi oleh responden berjenis kelamin wanita, yaitu $67,6 \%$ berjenis kelamin wanita. Hal ini dapat disebabkan oleh adanya kecenderungan wanita, untuk lebih peduli terhadap kesehatan, termasuk aktivitas fisik yang mendukung kesehatan, serta penggunaan pelayanan kesehatan (Akhmad et al., 2015). Di sisi lain, pada kelompok pekerja, pekerja dengan jenis kelamin pria memiliki kecenderungan memiliki tingkat aktivitas fisik yang lebih tinggi dibandingkan wanita (Cheah \& Poh, 2014) Sebagian besar responden pada penelitian ini memiliki tingkat pendidikan $\mathbf{S 1}$, yaitu sebanyak $70,6 \%$ dari total responden. Tingkat pendidikan sendiri dapat mempengaruhi 
perilaku aktivitas fisik seseorang, tinggi tingkat pendidikan yang lebih tinggi dapat menjadikannya semakin memiliki kemampuan menggunakan perangkat teknologi yang dapat menurunkan aktivitas fisik (Abadini \& Wuryaningsih, 2019). Hal ini juga dapat disebabkan oleh peningkatan aktivitas lainnya, (Cheah \& Poh, 2014 \& Lechner, 2009) maupun dapat meningkatkan kesadarannya akan pentingnya aktivitas fisik, seseorang dengan aktivitas fisik yang baik, didukung oleh pengetahuan yang baik pula (Roring et al., 2020)

Persepsi merupakan cara pandang seseorang termasuk di dalamnya cara mengidentifikasi suatu paparan terhadap sistemnya, meliputi pengelihatan, pendengaran dan sebagainya (Ou, 2017). Proses pembentukan persepsi terdiri atas tiga tahapan besar meliputi, seleksi, organisasi informasi dan interpretasi (Ou, 2017). Persepsi seseorang terhadap aktivitas fisik dan manfaatnya memberikan pengaruh terhadap perilaku aktivitas fisiknya (Purnamasari, et al 2019) sehingga perlu dikaji apakah jenis kelamin memberikan pengaruh terhadap persepsi responden.

Sama halnya seperti jenis kelamin, berdasarkan hasil analisis korelasi antara tingkat pedidikan dengan persepsi karyawan $(p=0,396 r=-0,150)$ artinya tidak ada hubungan antara tingkat pendidikan dengan persepsi terhadap senam peregangan. Hal ini bertolak belakang dengan hasil penelitian yang dilakuka oleh Iriyanto \& Winaryati (2010) yang menyatakan adanya perbedaan persepsi antara laki-laki dengan perempuan dalam berpendapat terhadap suatu hal. Namun, pada penelitian ini ditemukan bahwa baik tenaga kesehatan laki-laki dan perempuan sama-sama memiliki persepsi baik terhadap aktivitas fisik, sehingga tidak ada hubungan antara jenis kelamin dengan persepsi. Sejalan dengan penelitian Justine (2020) yang tidak melakukan pembedaan pengukuran persepsi berdasarkan jenis kelamin.

Menganalisis hubungan antara pengetahuan terkait manfaat aktivitas fisik dengan persepsi karyawan terhadap senam peregangan. Berdasarkan hasil analisis korelasi spearman diperoleh ( $p=0,032 r=0,396)$ artinya ada hubungan antara pengetahuan dengan persepsi mengenai senam peregangan. Dengan arah hubungan positif, berarti semakin baik pengetahuan tenaga Kesehatan, maka persepsi mengenai aktivitas fisik juga semakin baik. Persepsi seseorang dapat menjadi batasan internal yang membatasi aktivitas fisik seseorang, persepsi dapat terbentuk dari berbagai hal meliputi pengetahuan tentang manfaat dari aktivitas fisik (Jun, et al, 2020). Pengetahuan merupakan hal penting 
yang dimiliki seseorang terutama tenaga Kesehatan, dari pengetahuan yang baik akan tercipta persepsi yang baik pula dan pada akhirnya membangun prilaku yang baik (Jun et al, 2020). Peningkatan pengetahuan dapat diberikan dengan media yang menarik, mudah dipahami dan dapat diterima oleh berbagai kalangan seperti buku saku (Festiawan \& Arovah, 2020).

\section{SIMPULAN}

Berdasarkan hasil penelitian terdapat hubungan antara pemahaman terkait manfaat aktivitas fisik dengan persepsi terhadap senam peregangan. Sedangkan arah hubungan koefisien korelasi positif, berarti pemahaman terkait manfaat aktivitas fisik menentukan persepsi terhadap senam peregangan. Agar hasil penelitian ini dapat digunakan untuk mengembangkan hasil penelitian senam peregangan diperlukan koordinasi mengenai pengisian kuesioner agar hasil penelitian bisa lebih maksimal dan pengumpulan responden yang lebih massif.

\section{REFERENSI}

Abadini, D., \& Wuryaningsih, C. E. (2019). Determinan Aktivitas Fisik Orang Dewasa Pekerja Kantoran di Jakarta Tahun 2018. Jurnal Promosi Kesehatan Indonesia, 14(1).

Adi, \& Sapto. (2020). Model-Model Exercise Dan Aktivitas Fisik Untuk Kebugaran Jasmani Anak SD. Malang. In Wineka Media.

Adittia, A. (2017). Penggunaan Media Pembelajaran Audio Visual Untuk Meningkatkan Hasil Belajar Ips Pada Siswa Kelas Iv Sd. Journal Upi, 4(1), 9-20. https://doi.org/10.23819/mimbar-sd.v4i1.5227

Akhmad, A. D., Satibi, \& Puspandari, D. A. (2015). Analisis Persepsi dan Faktor Yang Mempengaruhi Persepsi Terhadap Penerapan Sistem Pembiayaan JKN Pada Fasilitas Kesehatan Penunjuan Di D.I. Yogyakarta. Jurnal Manajemen Dan Pelayanan Farmasi, 5(4).

Budi, D. R., Widyaningsih, R., Nur, L., Agustan, B., Dwi, D. R. S., Qohhar, W., \& Asnaldi, A. (2021). Cycling during covid-19 pandemic: Sports or lifestyle? International Journal of Human Movement and Sports Sciences, 9(4), 765-771. https://doi.org/10.13189/saj.2021.090422

Cheah YK, Poh BK. The Determinants of Participation in Physical Activity in Malaysia. Osong Public Heal Res Perspect [Internet]. 2014 [ 
COVID-19, S. T. P. (2020). Data COVID-19 di Indonesia.

Festiawan, R., \& Arovah, N. I. (2020). Pengembangan "Buku Saku Pintar Gizi" Untuk Siswa" Alternatif Media Pembelajaran untuk Meningkatkan Pengetahuan Gizi Olahraga. Jurnal PAJU, 1(2), 188-201.

Ibrahim S, Karim NA, Oon NL, Zurinah W, Ngah W. Perceived physical activity barriers related to body weight status and sociodemographic factors among Malaysian men in Klang Valley. 2013

Iriyanto, S., \& Winaryati, E. (2010). Perbedaan Persepsi Antar Jenis Kelamin Terhadap Peran Gender Dalam Keluarga dan Masyarakat. Jurnal Unimus, 210-221.

Justine M, Azizan A, Hassan V, Salleh Z, Manaf H. Barriers to participation in physical activity and exercise among middle-aged and elderly individuals. Singapore Med J. 2013;54(10):581-6.

Nui Jia Jun , Khairil Shazmin Kamarudin, Asma Ali, Noor Salihah Zakaria. Motivators and Barriers of Physical Activity among Private Office Workers in Selangor . Mal J Med Health Sci 16(1): 58-65, Jan 2020

Lechner M. Long-run labour market and health effects of individual sports activities. $J$ Health Econ. 2009 Jul;28(4):839-854

Ou Qiong. A brief introduction to peceptio. Studies in Literature and Language Vol. 15, No. 4, 2017, pp. 18-2 DOI:10.3968/10055

P2PTM, Kemenkes. (2018). Aktivitas Fisik Berat.

Purnamasari,A. , Astiti, D., Santoso, N.K, Hubungan Persepsi Manfaat Aktivitas Fisik dengan Aktivitas Fisik pada Lansia Hipertensi di Wilayah Kerja Puskesmas Bantul 1 Yogyakarta. Manuskrip 2019

Roring, N. M., Posangi, J., \& Manampiring, A. E. (2020). Hubungan antara pengetahuan gizi, aktivitas fisik, dan intensitas olahraga dengan status gizi. Jurnal Biomedik, 12(2), 110-116.

Sechrist, \& R, K. (1987). Health Promotion Model - Instrument to Measure HPM Behavioral Determinants: Exercise Benefits/Barriers Scale (EBBS).

Sugiono, \& Arif. (2020). Sebaran Data Tenaga Medis Gugus Akibat COVID-19. Gatra.

Sumarni, S. (2015). Hubungan Persepsi Kesehatan Prima Dengan Aktivitas Kehidupan Sehari-Hari Pada Lansia Yang Menderita Nyeri Sendi Di UPT Puskesmas Pamolokan Sumenep. Jurnal Kesehatan Wiraraja Medika, 87-94.

Wicaksono, \& Ariif. (2020). Aktivitas Fisik Yang Aman Pada Masa Pandemi COVID-19. Jurnal Ilmu Keolahragaan Undiskha, 18(1), 10-15. 
Widanita, N., Kusuma, M. N. H., Budi, D. R., Suhartoyo, T., Listiandi, A. D., Anggraini, D., \& Gitya, N. (2019). The Effectiveness of Pilates Training Moderl Towards BMl and Muscle Mass. Annals of Tropical Medicine \& Public Health, 11(December)

Yudho, F. H. P., Rahadian, A., Aryani, M., Afriyuandi, A. R., \& Pratama, A. K. (2020). Tingkat Persepsi dan Ketertarikan Masyarakat Dalam Aktivitas Fisik Berirama Dalam Menjaga Kebugaran Fisik. Jurnal Terapan IImu Keolahragaan, 5, 125-133. 